\title{
Controlled Morphology of Silica Particle by Spray Drying Method
}

\author{
Abdurrahman Anis Albar, Widiyastuti, and Heru Setyawan \\ Department of Chemical Engineering, Institut Teknologi Sepuluh Nopember, Surabaya \\ e-mail: widi@chem-eng.its.ac.id
}

\begin{abstract}
The controlled morphology of mesoporous silica particle with colloidal silica as precursor solution was investigated using spray drying method. The colloidal silica solution was made from sodium silicate (waterglass) using solgel method. The operating condition of spray dring such as precursor solution volumetric rate and hot air flowrate was varied to study the effect of the silica particle's morphology. Two-fluid nozzle was used as atomizer with volumetric rate ranged from $1.6 \mathrm{~mL} / \mathrm{min}$ to $5 \mathrm{~mL} / \mathrm{min}$, and hot air heated from tubular furnace with flowrate ranged from $210 \mathrm{~L} / \mathrm{min}$ to 414 $\mathrm{L} / \mathrm{min}$, both resulting doughnut-like shape with more doughnut fraction with increased volumetric rate. With the increase of volumetric rate from $1.6 \mathrm{~mL} / \mathrm{min}$ to $5 \mathrm{~mL} / \mathrm{min}$, the surface area and total pore volume are tend to decrease (168.234 to 131.001 $\mathrm{m}^{2} / \mathrm{g}$ and 0.1652 to $0.1251 \mathrm{cc} / \mathrm{g}$ respectively). Meanwhile, for increasing hot air flowrate from $210 \mathrm{~L} / \mathrm{min}$ to $414 \mathrm{~L} / \mathrm{min}$, the surface area are tend to increase $\left(135.353\right.$ to $\left.168.234 \mathrm{~m}^{2} / \mathrm{g}\right)$ but total pore volume tend to decrease $(0.1921$ to $0.1652 \mathrm{cc} / \mathrm{g})$.
\end{abstract}

Keywords-Morphology, Silica Particle, Spray Drying, TwoFluid Nozzle, Waterglass.

\section{INTRODUCTION}

$\mathrm{S}$ ILICON dioxide (silica) is one of the most used utilized nanomaterial because it can be used in various application, with increased of 5,6 percentage per year and projected to 2.8 million in 2016 [1]. As functional material, silica is commonly found in market as porous particle. Silica with pore size 2-50 micrometers (defined as mesoporous silica) is widely known as one of the main topics of porous material research because its uniformity and high specific surface area $[2,3]$. There is plenty potential of the mesoporous silica potential as such as catalyst and adsorbent, with their use in separation column [4]. Several method has been attempted for preparing silica particle, such as chemical vapour deposition, flame spray pyrolysis, micro-emulsion, ball miling and spray drying have resulted large amount of important publication.

Spray drying is known as an aerosol-assisted self-assembly method combined with drying process to produce dry powder from liquid, commonly used for powder processing from field associated with food, catalyst, pharmacy and other process. This method is commonly used in due to its system simplicity, cost effectivity and can be scaled up to ton quantity in industry [5]. Moreover, this flexible method is suitable with variable material that throw most benefit from this process.

Among the other particle processing method, spray drying is one of the best for particle production because its controllable size that ranged from micrometer to nanometer with just changing the process parameter $[6,7]$. By adjusting this method with suitable process, whether the raw material condition (for example : chemical and physical properties, type of material, surface charge and initial particle size) or process condition will be an important role on the production of the product with various shape [8].

Colloidal nanosilica is a stable dispersion of liquid containing silica nanoparticle and can be prepared from various starting material and method to produce silica particle. Lim et al. [9] compared several preparation methods of colloidal silica, namely ion exchange, hydrolysis \& condensation, dispersion and oxidation. Hydrolysis \& condensation method commonly using tetraethyl orthosilicate (TEOS) or tetramethyl orthosilicate (TMOS) generating least imurity, but hampered to used in large-scale industry due to its high-cost and hazardous material [10]. Sodium silicate (known as waterglass) is an alternative of cheap starting material for preparing colloidal silica solution, involving ion exchange of natrium and sol-gel method. This material would be preferred by industry due to its cheap prize and easy size controlled.

In this study, silica sol was synthesized by colloidal silica using sol-gel method from waterglass at ambient temperature then followed by spray dried to obtain dry silica particle. Liquid volumetric rate and hot air flowrate was varied to study the effect on the morphology control of the silica particle.

\section{METHODS}

Precursor solution was made using sol-gel method. Waterglass $\left(\mathrm{Na}_{2} \mathrm{SiO}_{3}\right.$ with $28 \%$ wt $\mathrm{SiO}_{2}$, PT PQ Silica Pasuruan) was used as silica source with activated cation resin (amberlite) to exchange sodium ion with $\mathrm{H}^{+}$at the same volume ratio. 0.1 M Potassium Hidroxide ( $\mathrm{KOH}$, merck) was titrated drop-by-drop until the sol reached $\mathrm{pH}$ value of 8 . Spray dryer (TEFIC) has two fluid nozzle as atomizer as shown in Figure 1. The colloidal sol with $1.8 \%$ wt was sprayed in two-fluid nozzle atomizer with sol flowrate (1.6; 3.3 and $5 \mathrm{ml} / \mathrm{min}$ ) being adjusted with peristaltic pump, and carrier gas was heated by blowing ambient air into tubular furnace with the hot air flowrate $(210,288$ and $414 \mathrm{~L} / \mathrm{min})$ was varied, and the spray drying temperature was set constant at $200^{\circ} \mathrm{C}$.

The morphology and the size of $\mathrm{SiO}_{2}$ particle was observed using HITACHI FLEXEM 100 scanning electron microscopy and the sol size distribution sampled at least 200 samples to show size distribution using imageJ application. The BET surface area, BJH pore size distribution and pore volume method was measured using full isotherm adsorptiondesorption isotherms methods using nitrogen gas and 
The $6^{\text {th }}$ International Seminar on Science and Technology (ISST) 2020

July $25^{\text {th }} 2020$, Institut Teknologi Sepuluh Nopember, Surabaya, Indonesia

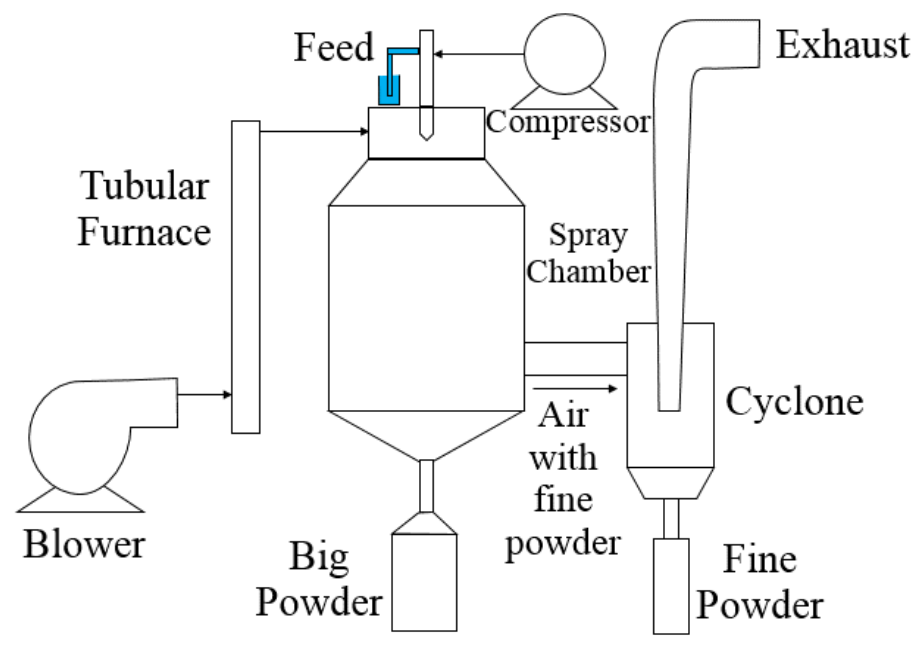

Figure 1. Spray Drying Experiment Apparatus.
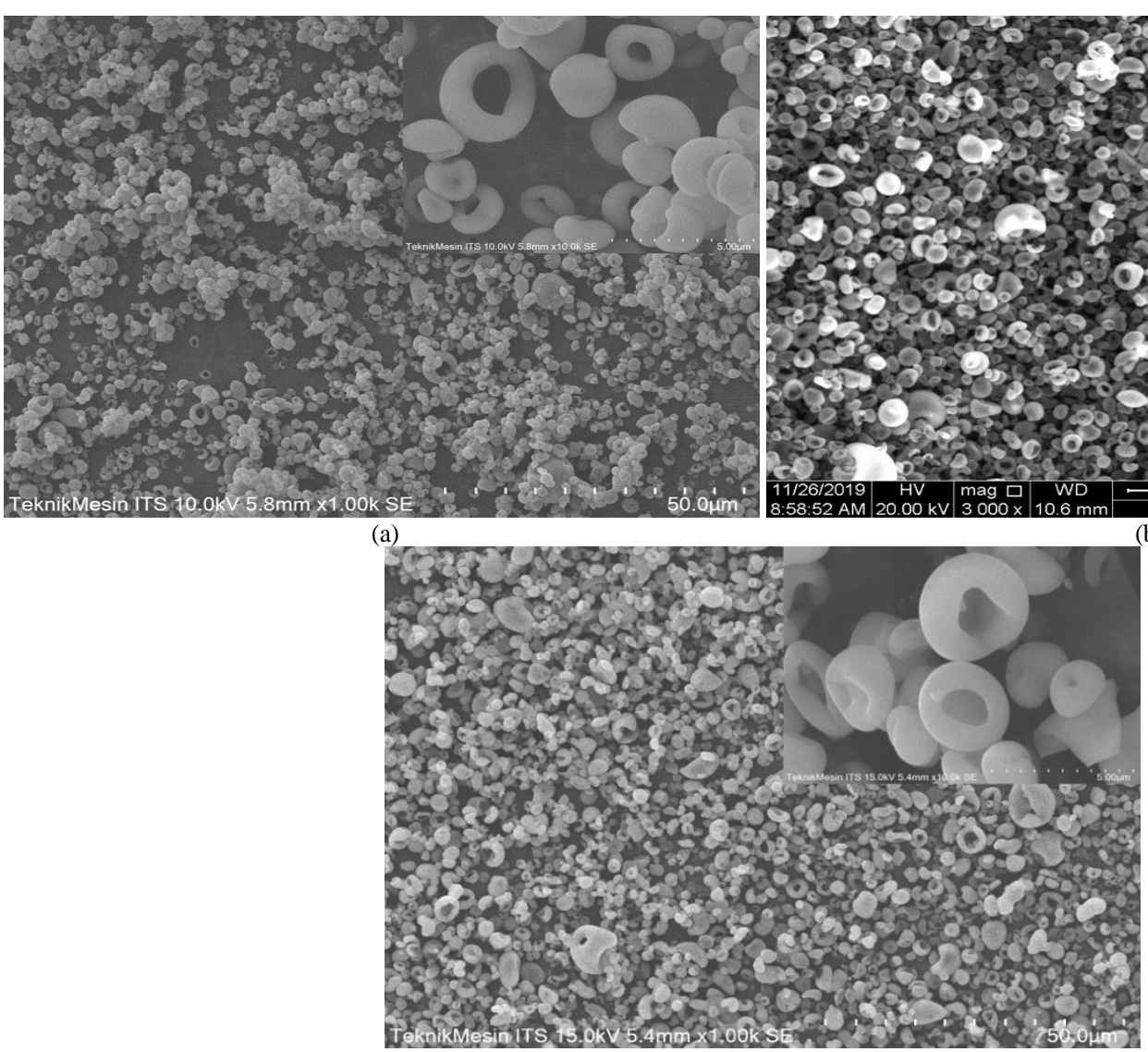

Figure 2. SEM image of spray dried particle with liquid volumetric rate $\mathrm{V}_{\mathrm{L}}$ (a) $1.6 \mathrm{~mL} / \mathrm{min}$; (b) $3.3 \mathrm{~mL} / \mathrm{min}$; (c) $5 \mathrm{~mL} / \mathrm{min}$.

measured at the boiling point temperature (Quantachrome's NOVA1200e).

\section{RESULTS AND DISCUSSION}

Silica particle were synthesized from colloidal silica precursor solution by spray drying method. Figure 2 shows SEM image of the morphologhy of spray dried particle with liquid volumetric rate $\left(\mathrm{V}_{\mathrm{L}}\right) 1.6 ; 3.3 ; 5 \mathrm{~mL} / \mathrm{min}$.

It can be seen that for all particle dominated by doughnut then followed by spherical particle, with fraction of doughnut-like particle from total particle is $73.8 \%$; $80.6 \%$ and $81 \%$, respectively for value of $\mathrm{V}_{\mathrm{L}} 1,6 \mathrm{~mL} / \mathrm{min} ; 3,3$ (c)

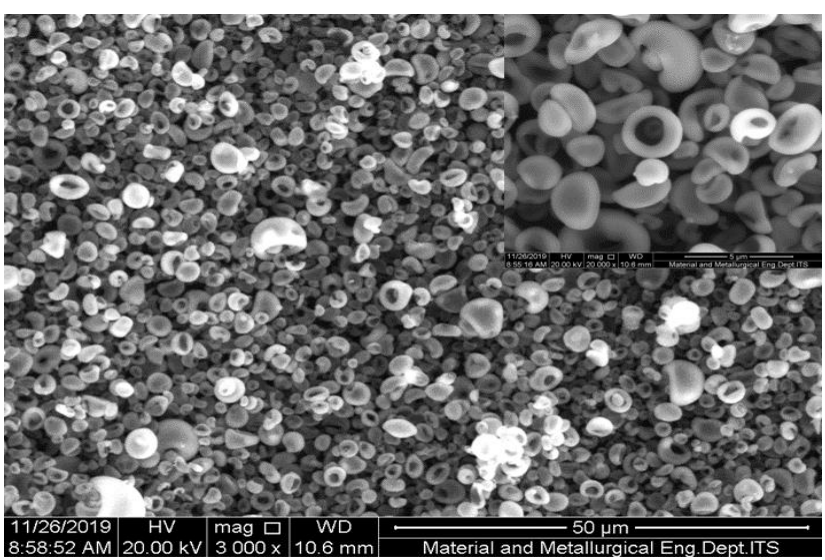

$\mathrm{ml} / \mathrm{min}$ and $5 \mathrm{~mL} / \mathrm{min}$. This is indicating that as increased of $\mathrm{V}_{\mathrm{L}}$, the particle particle tend to more in the doughnut-like form than in the spherical form. The initial deformation of the unstable droplet taking place when high flowrate of the hot air used in this process resultsing doughnut-like morphologhy. The unstable structure of a droplet in twophase flow field occurs due to an additional marco and microdynamics effects in the drying process [5].

From the SEM images, particle size distribution with calculated average geometric diameter and geometric standard deviation for various value of $\mathrm{V}_{\mathrm{L}}$ shown in Figure 3. The particle size distribution shows almost uniform size distribution in all $\mathrm{V}_{\mathrm{L}}$ value and the particle geometric 
The $6^{\text {th }}$ International Seminar on Science and Technology (ISST) 2020

July $25^{\text {th }}$ 2020, Institut Teknologi Sepuluh Nopember, Surabaya, Indonesia

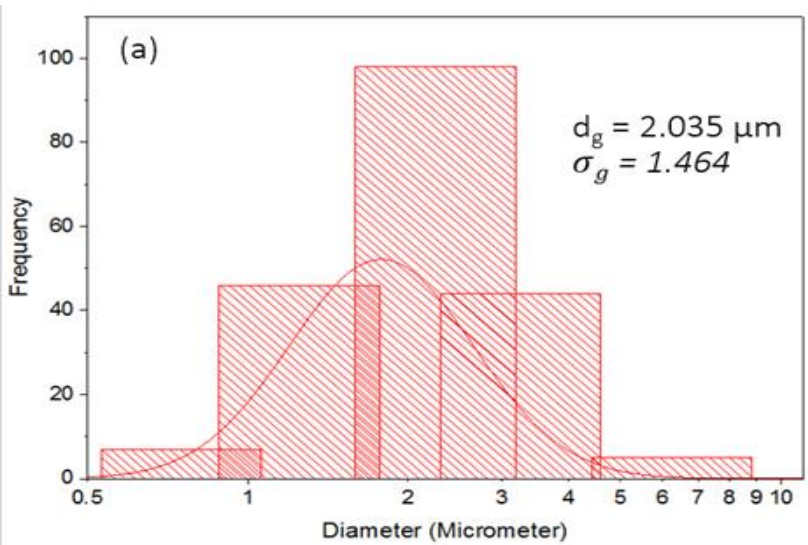

(a)

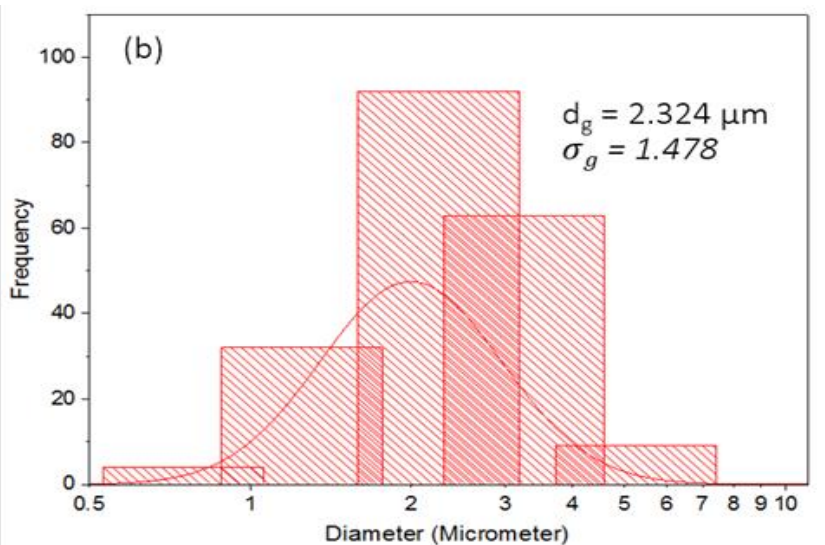

(b)

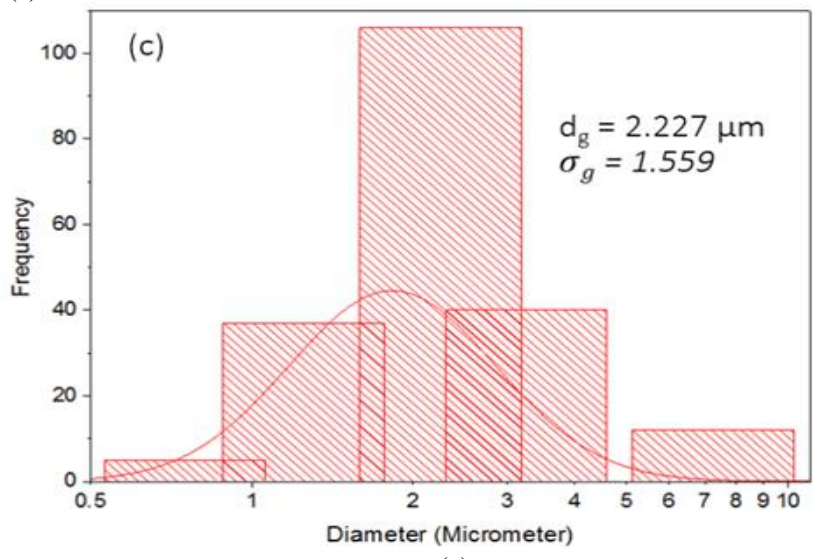

(c)

Figure 3. Particle size distribution with liquid volumetric rate (a) $1.6 \mathrm{~mL} / \mathrm{min}$; (b) $3.3 \mathrm{~mL} / \mathrm{min}$; (c) $5 \mathrm{~mL} / \mathrm{min}$.

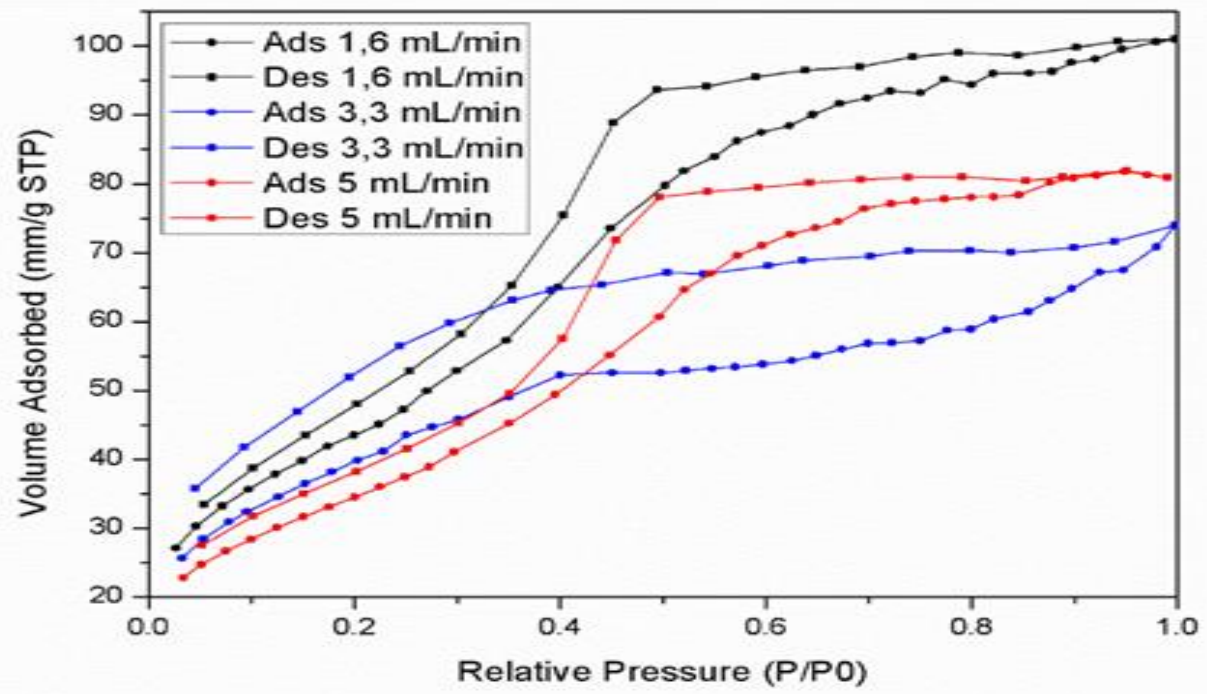

Figure 4. $\mathrm{N}_{2}$ adsorption-desorption curve for various value of $\mathrm{V}_{\mathrm{L}}$.

diameter increase as value of $\mathrm{V}_{\mathrm{L}}$ increase. The increase of the feed volumetric rate can induced the coallision of small drop that subsequently fused thus the particle size would be increased [11].

Figure 4 shows $\mathrm{N}_{2}$ at $77 \mathrm{~K}$ adsorption-desorption isotherms curve for all $\mathrm{V}_{\mathrm{L}}$ value and Figure 5 shows its pore size distribution. According to IUPAC classification, all the curve classified with type IV which classified for mesoporous particle [12]. This type of curve attributed to monolayermultilayer adsoption, which characterized with almost linear in the middle section of isotherm that indicates completion of the monolayer adsorption and start of the multilayer adsorption. The hysteresis in the multilayer range classified with $\mathrm{H} 2$ for $\mathrm{V}_{\mathrm{L}}$ value of 1.6 and $5 \mathrm{~mL} / \mathrm{min}$ attributed to pore narrow mouth and wide bodies, meanwhile $\mathrm{H} 4$ hysteresis for $3.3 \mathrm{~mL} / \mathrm{min}$ attributed to slit-pore structure and broad size distribution as shown in Figure 5 with near identical peak of $1 \mathrm{cc} / \mathrm{g}$ at the diameter of $3.4 \mathrm{~nm}$ for $\mathrm{V}_{\mathrm{L}}$ value of 1.6 and 5 $\mathrm{mL} / \mathrm{min}$. The data of specific surface area, total pore volume and average pore size was shown in Table 1 . As increased $V_{L}$ value, total pore volume and BET specific surface area was tend to decrease, meanwhile average pore size was tend to increase so the highest specific surface area obtained for $V_{L}$ value of $1.6 \mathrm{~mL} / \mathrm{min}$. 
The $6^{\text {th }}$ International Seminar on Science and Technology (ISST) 2020

July $25^{\text {th }} 2020$, Institut Teknologi Sepuluh Nopember, Surabaya, Indonesia

Table 1.

Specific surface area, average pore size and total pore volume data for various value of volumetric precursor rate

\begin{tabular}{cccc}
\hline \hline Volumetric Precursor Rate & Specific Surface Area $\left(\mathrm{m}^{2} / \mathrm{g}\right)$ & Average Pore Size $(\mathrm{nm})$ & Total Pore volume $(\mathrm{cc} / \mathrm{g})$ \\
\hline $1,6 \mathrm{~mL} / \mathrm{min}$ & 168,234 & 3,714 & 0,1652 \\
$3,3 \mathrm{~mL} / \mathrm{min}$ & 145,300 & 3,151 & 0,1145 \\
$5 \mathrm{~mL} / \mathrm{min}$ & 131,001 & 3,820 & 0,1251 \\
\hline \hline
\end{tabular}

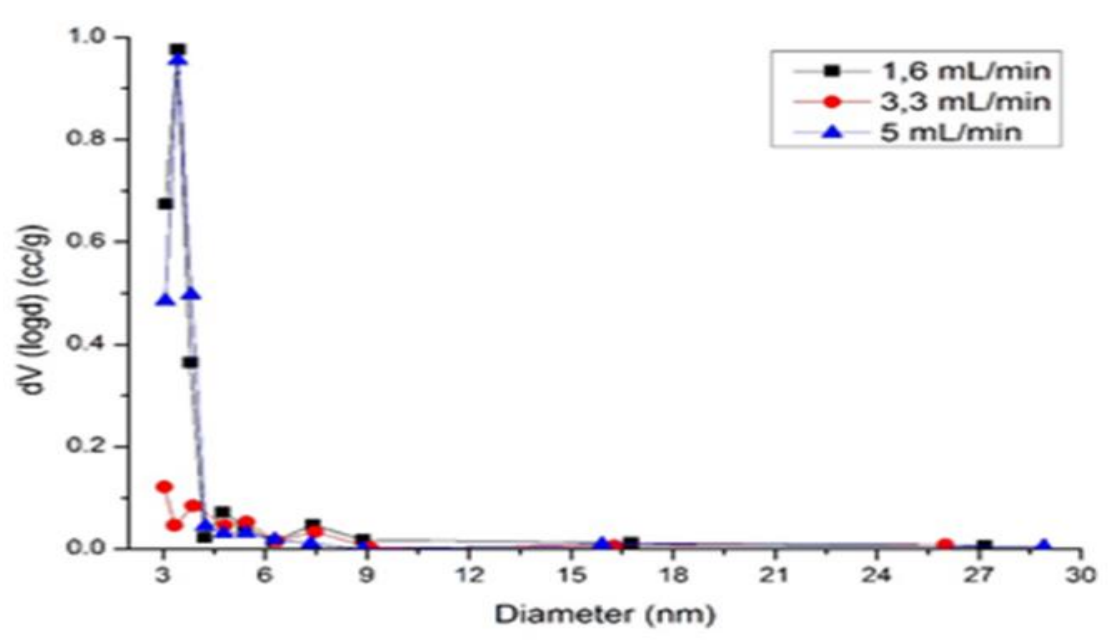

Figure 5. Pore size distribution curve for various value of $\mathrm{V}_{\mathrm{L}}$.

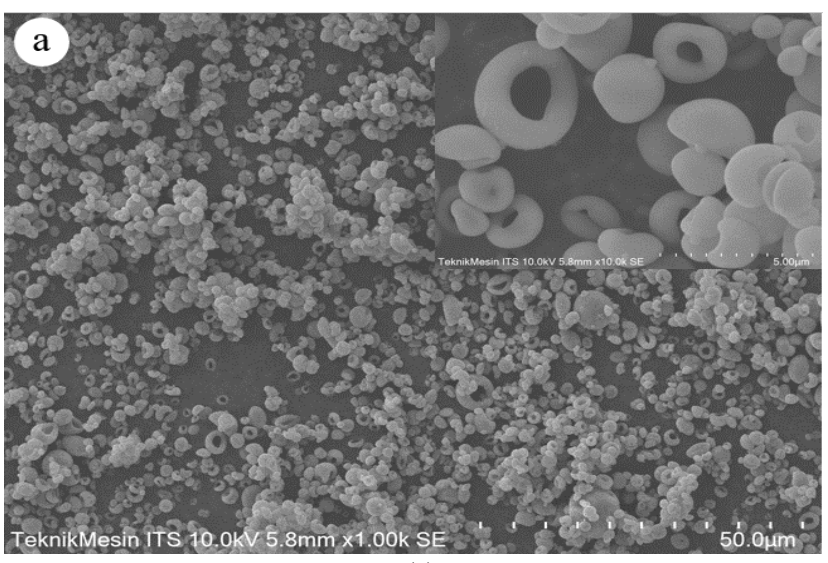

(a)

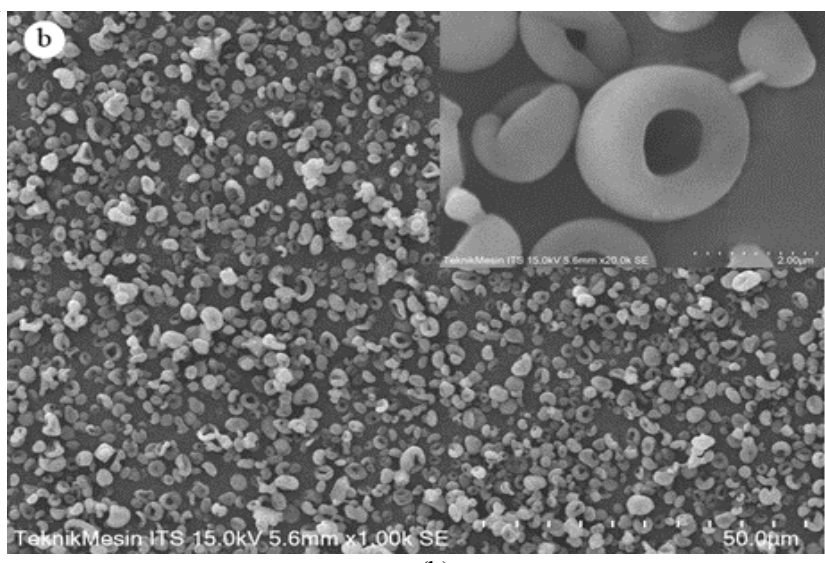

(b)

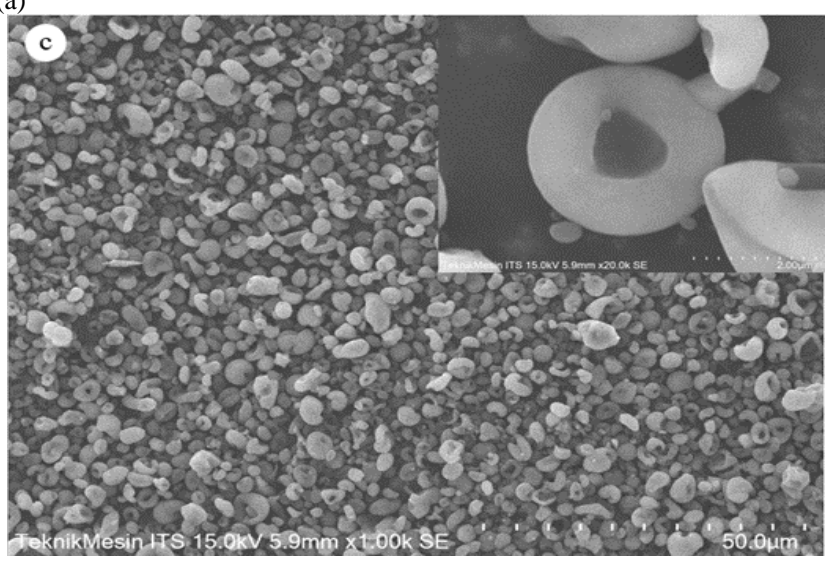

(c)

Figure 6. SEM image of spray dried particle with hot air flowrate (a) $414 \mathrm{~L} / \mathrm{min}$; (b) $288 \mathrm{~L} / \mathrm{min}$; (c) $210 \mathrm{~L} / \mathrm{min}$.

The morphology of silica particle with various value of hot air flowrate from SEM images shown in Figure 6 with value of hot air flowrate was 414, 288 and $210 \mathrm{~L} / \mathrm{min}$. The differences of the hot air flowrate referring to the drying rate in the spray chamber, thus the resident time in the chamber will be shorter as hot air flowrate increased. Peclet (Pe) number define the quantitative measurement of the drying strength, as the ratio of time required for a solute to diffuse from the edge of the droplet to its center $\left(R^{2} / D\right)$ per time required for a droplet to dry $\left(\tau_{d}\right)$ into the equation of $\mathrm{Pe}=$ $\mathrm{R}^{2} / \mathrm{D} \tau_{\mathrm{d}}$. Here,

$\mathrm{R}$ is the radius of the droplet in $\mathrm{m}, \mathrm{D}$ is the solute diffusion coefficient in $\mathrm{m}^{2} / \mathrm{s}$. To calculate diffusion coefficient, the Stoke-Einstein equation was used, $D=k_{B} T /\left(6 \pi \eta R_{H}\right)$, with $k_{B}$ is Boltzmann constant in $\mathrm{m}^{2} \mathrm{~kg} / \mathrm{s}^{2} \mathrm{~K}$, $\mathrm{T}$ is the temperature of the solution in $K, \eta$ is viscosity of the solution in $\mathrm{kg} / \mathrm{ms}, \mathrm{R}_{\mathrm{H}}$ 
The $6^{\text {th }}$ International Seminar on Science and Technology (ISST) 2020

July $25^{\text {th }} 2020$, Institut Teknologi Sepuluh Nopember, Surabaya, Indonesia

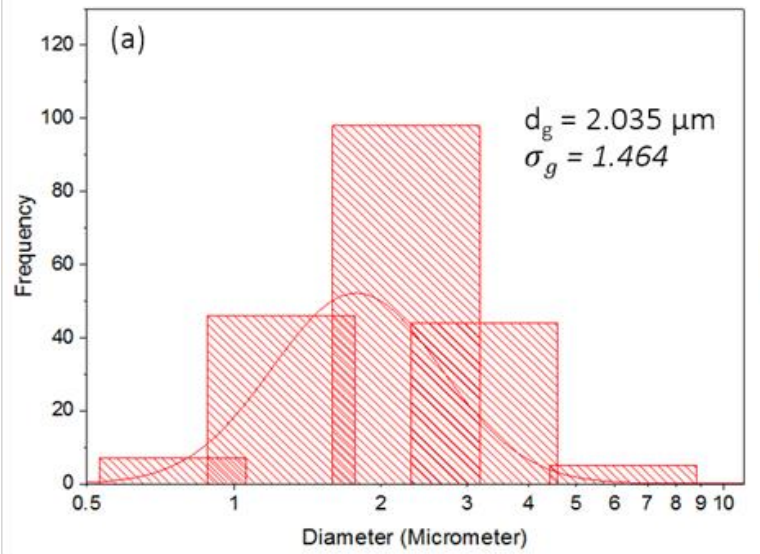

(a)

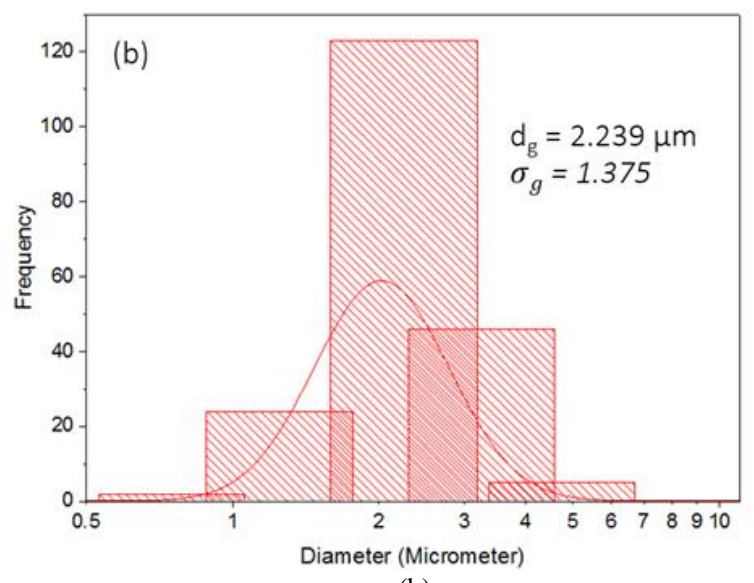

(b)

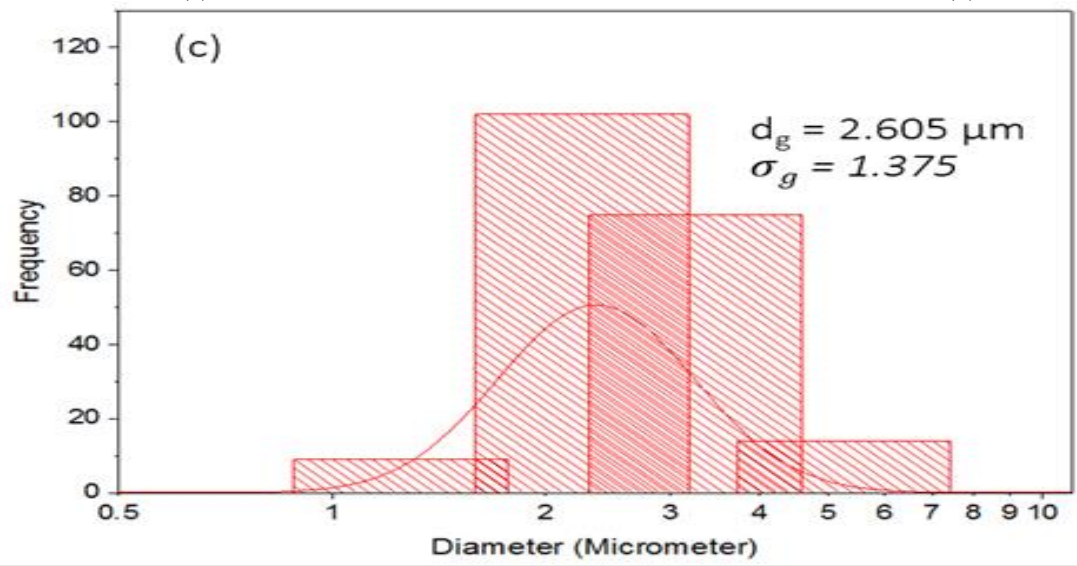

(c)

Figure 7. Particle size distribution with hot air flowrate (a) $414 \mathrm{~L} / \mathrm{min}$; (b) $288 \mathrm{~L} / \mathrm{min}$; (c) $210 \mathrm{~L} / \mathrm{min}$.

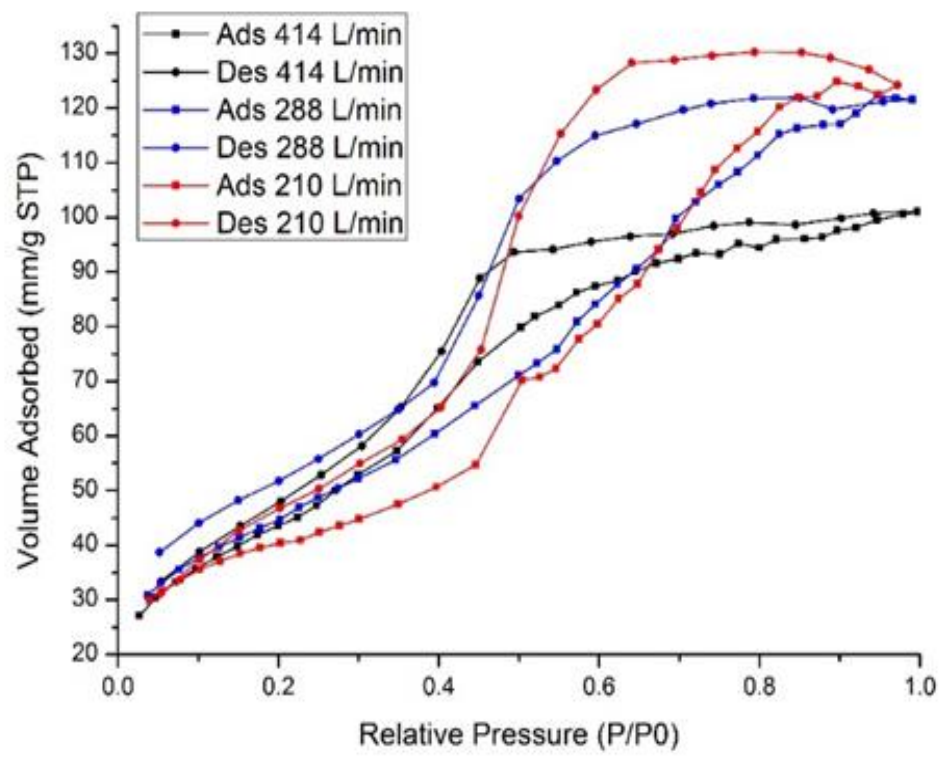

Figure 8. $\mathrm{N}_{2}$ adsorption-desorption curve for various value of hot air flowrate.

is the hydrodynamic radius of the solute. Entering the parameter value of $\mathrm{k}_{\mathrm{B}}=1.38 \times 10^{-23}, \mathrm{~T}=303 \mathrm{~K}, \eta=1.007 \times 10^{-}$ ${ }^{3} \mathrm{~kg} / \mathrm{ms}, \mathrm{R}_{\mathrm{H}}=7.6 \times 10^{-9} \mathrm{~m}$, the $\mathrm{D}$ has a value of $2.9 \times 10^{-9} \mathrm{~m}^{2} / \mathrm{s}$. The droplet diameter calculated approximately 8.61 micrometer and drying time for hot air flowrate 414, 288 and $210 \mathrm{~L} / \mathrm{min}$ was $2.70 ; 3.88$ and 5.32 respectively. The value of the peclet number was $0.95 ; 0.66$ and 0.48 for hot air flowrate 414, 288 and $210 \mathrm{~L} / \mathrm{min}$, respectively. These hot air flowrate was considered as moderate drying process with value of
Peclet number $<1$, meaning the diffusional movement faster than receding droplet surfaces radial velocity [13].

Particle size distribution, average geometric diameter and geometric standard deviation for various value of hot air flowrate shown in Figure 7. It can be seen that particle size getting bigger with slower hot air flowrate, and particle size distribution almost uniform. Increased drying air flowrate affecting more energy for fluid dispersion thus decreased particle size [14]. 
The $6^{\text {th }}$ International Seminar on Science and Technology (ISST) 2020

July $25^{\text {th }} 2020$, Institut Teknologi Sepuluh Nopember, Surabaya, Indonesia

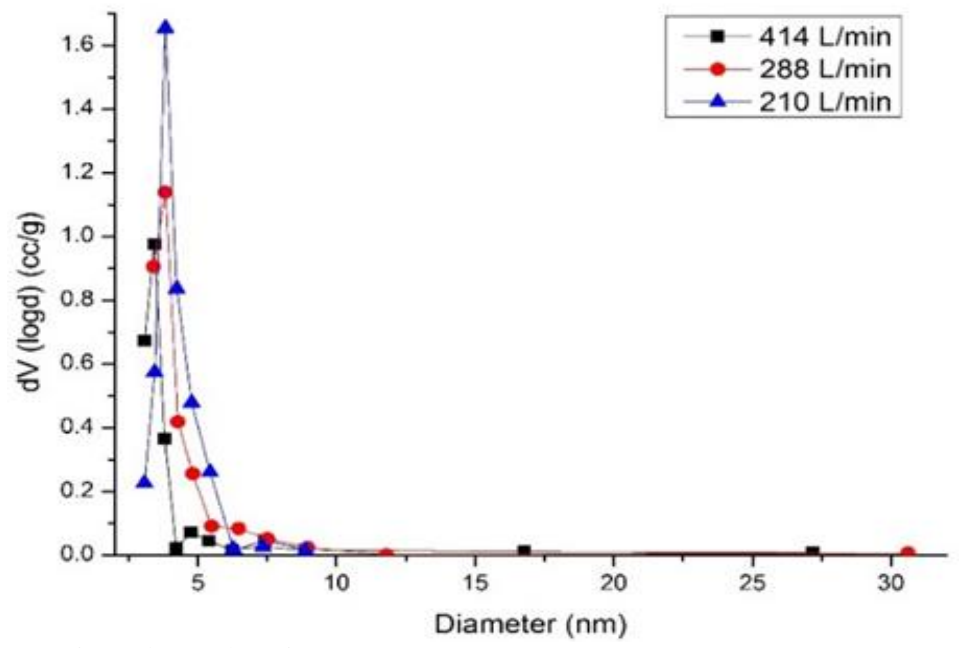

Figure 9. Pore size distribution curve for various value of $\mathrm{V}_{\mathrm{L}}$.

Table 2.

Specific surface area, average pore size and total pore volume data for various value of hot air flowrate

\begin{tabular}{cccc}
\hline \hline Hot Air Flowrate & Specific Surface Area $\left(\mathrm{m}^{2} / \mathrm{g}\right)$ & Average Pore Size $(\mathrm{nm})$ & Total Pore volume $(\mathrm{cc} / \mathrm{g})$ \\
\hline $414 \mathrm{~L} / \mathrm{min}$ & 168,234 & 3,714 & 0,1652 \\
$288 \mathrm{~L} / \mathrm{min}$ & 164,314 & 4,577 & 0,1880 \\
$210 \mathrm{~L} / \mathrm{min}$ & 135,353 & 5,678 & 0,1921 \\
\hline \hline
\end{tabular}

The BET adsorption-desorption curve in Figure 8 classified all of the curve as type IV and all hystheresis as type $\mathrm{H} 2$ which means no change occurred both on the curve or type of hystheresis, and pore size distribution curve shown in Figure 9 shows higher pore volume distribution peak with $1.14 \mathrm{cc} / \mathrm{g}$ for hot air flowrate $288 \mathrm{~L} / \mathrm{min}$ and increased further to $1.65 \mathrm{cc} / \mathrm{g}$ for hot air flowrate $414 \mathrm{cc} / \mathrm{g}$, both at the diameter of $3.8 \mathrm{~nm}$. The data of the specific surface area, average pore size and total pore volume in Table 2 shows that specific surface area increased as hot air flowrate increased, but the average pore size and total pore volume decrease with highest specific surface area for hot air flowrate of $414 \mathrm{~L} / \mathrm{min}$.

\section{CONCLUSION}

The effect of liquid volumetric rate and hot air flowrate on the silica particles morphology was investigated. The result shows higher liquid volumetric rate and lower hot air flowrate would result increase in particle size with range of size from 2,035 to $2,605 \mu \mathrm{m}$, meanwhile the fraction of the doughnut increased with higher liquid flowrate. The porosity analysis shown BET specific surface area was ranged from 131,001 to $168,234 \mathrm{~m}^{2} / \mathrm{g}$, with pore diameter ranged from 3,151 to 5,678 $\mathrm{nm}$ and total pore volume ranged from 0,1145 to $0,1921 \mathrm{cc} / \mathrm{g}$.

\section{REFERENCES}

[1] L. Lazaro, L. Benac-Vegas, H. J. H. Brouwers, J. W. Geus, J. Bastida "The kinetics of olivine dissolution under the extreme conditions of nano-silica production," Applied Geochemistry, vol. 52, pp. 1-15, Jan 2015.

[2] C. T. Kresge, M. Leonowicz, W. J. Roth, J. C. Vartuli, J. S. Beck, "Ordered mesoporous molecular sieves synthesized by a liquid-crystal template mechanism," Nature, vol. 359, pp. 710-712, 1992.

[3] J. S. Beck, J. C. Vartuli, W. J. Roth, M. E. Leonowicz, C. T. Kresge, K. D. Schmitt, C. T. W. Chu, D. H. Olson, E. W. Sheppard, S. B. McCullen, J. B. Higgins, J. L. Schlenker, "A new family of mesoporous molecular sieves prepared with liquid crystal template," Journal of the American Chemical Society, vol. 114, pp. 10834-10843, Dec 1992.

[4] Y. Yamada, K. Yano, "Synthesis of monodispered super microporous/mesoporous silica spheres with diameters in the low submicron range," Microporous and Mesoporous Material, vol. 93, pp. 190-198, Apr 2006.

[5] F. Iskandar, L. Gradon and K. Okuyama, "Control of the morphology of nanostructured particles prepared by the spray drying of a nanoparticle sol," Journal of Colloid and Interface Science, vol. 265, pp. 296-303, May 2003.

[6] K. Waldron, W. D. Wu, Z. Wu, W. Liu, C. Selomulya, D. Zhao and X. D. Chen, "Formation of monodisperse mesoporous silica microparticles via spray-drying," Journal of Colloid and Interface Science, vol. 418, pp. 225-233, Dec 2013.

[7] A. B. D. Nandiyanto and K. Okuyama, "Progress in developing spraydrying methods for production of controlled morphology particles : From the nanometer to submicrometer size ranges," Advance Powder Technology, vol. 22, pp. 1-19, Sept 2010.

[8] M. Abdullah, F. Iskandar, S. Shibamoto, T. Ogi and K. Okuyama, "Preparation of oxide particles with ordered macropores by colloidal templating and spray pyrolysis," Acta Materialia, vol. 52, pp. 51515156, Jul 2004.

[9] H. M. Lim, J. Lee, J. Jeong, S. Oh and S. Lee, "Comparative study of various preparation methods of colloidal silica," Scientific Research, vol. 2, pp. 998-1005, Nov 2010.

[10] P. B. Sarawade, J. Kim, A. Hilonga and H. T. Kim, "Preparation of hydrophobic mesoporous silica powder with a high specific surface area by surface modification of a wet-gel slurry and spray-drying" Powder Technology, vol. 197, pp. 288-294, Oct 2009.

[11] S. Al-Asheh, R. Jumah, F. Banat and S. Hammad, "The use experimental factorial design for analysing the effect of spray drying operating variables on the production of tomato powder," Trans IChemE, vol. 81 part C, pp. 81-88, June 2003.

[12] K. S. W. Sing, D. H. Everett, R. A. W. Haul, L. Moscou, R. A. Pierotti, J. Rouquerrol, T. Siemieniewska, "Reporting physisorption data for gas/solid systems with special reference to the determination of surface area and porosity," International union of pure and applied chemistry, vol. 57, no. 4, pp.603-619, 1985.

[13] R. Vehring, "Pharmaceutical particle engineering via spray drying," Pharmaceutical Research, Vol. 25, No. 5, May 2008.

[14] D. Senatore, J. Laven, R. A. T. M. V. Bentem, D. L. Camera, G. D. With, "Microencapsulation of epoxidized linseed oil liquid cross-linker in poly(n-vinyl-pyrrolidone) : optimization by design-of-experiments approach,” Ind. Chem. Eng. Res., Vol. 49, pp 3642-3653, 2010. 